\title{
Political Ambition in 14 Presidential Democracies
}

\author{
Theresa Kernecker \\ theresa.kernecker@univie.ac.at \\ Department of Government \\ University of Vienna*
}

\begin{abstract}
This article captures the nature of legislators' ambitions and explores to what extent their career paths within a context of party competition lead to progressive versus static ambition. The findings show that their previous career path and retrospective loyalty towards the party influences which offices they seek. Progressively ambitious legislators also seek offices in less competitive environments, but this finding holds for the regional executive branch or the presidency. An additional robust finding shows that ideologically conservative legislators tend to be statically ambitious. This is a first step towards mapping out ambitions in Latin America by drawing on cross-national data.
\end{abstract}

This is the peer reviewed version of the following article: Kernecker, Theresa (2016). "Political Ambition in 14 Presidential Democracies." Legislative Studies Quarterly 41.2: 393-417, which has been published in final form at https://onlinelibrary.wiley.com/doi/pdf/10.1111/lsq.12131. This article may be used for non-commercial purposes in accordance with Wiley Terms and Conditions for Use of Self-Archived Versions.

*Acknowledgements: I would like to thank two anonymous reviewers for their very helpful comments. I also thank Wolfgang C. Müller and my colleagues at the Department of Government for their helpful suggestions at different stages of this article. Special thanks go to Thomas Meyer for his input and time. I am also grateful to the University of Salamanca for making their survey data available to the research community. Research support was provided by the University of Vienna's uni:docs program. 


\section{Introduction}

To what extent do legislators draw on party versus personal resources in attaining their career goals within a context of party competition? This article tackles the nature of political ambition and legislators' behavior in 14 Latin American democracies. A closer look at the ambitions that individuals harbor merits attention for two main reasons: First, availability of individual data has allowed transcending parties as unitary actors and advanced the study of individual behavior in roll-call voting (Morgenstern and Nacif 2002), party-switching (Desposato 2006), party unity (Carey 2007, 2009), coalitions (Altman 2000), ministerial appointments (Camerlo 2013, 2014), or the role of ambition in legislative behavior (Botero 2008; Chasquetti 2010; Chasquetti and Micozzi 2014; Micozzi 2013; Samuels 2003, 2011). Second, recent institutional reforms aiming at improving the quality of representation have encouraged politicians to bring in a more personalized focus to politics (Karvonen 2010), emphasizing the importance of strategic politicians in tandem with a trend toward candidate-centered politics (Jacobsen 1989). Politicians aiming for a long-term political career can't depend solely on their parties in determining their fate. When planning career moves, they can either use their party as a vehicle to get further in their career or rely on personal resources to build their personal reputation independent from their party (Carey 2007). Studies have modeled how legislators adopt party or factionoriented behavior versus enhancing their own image (Chasquetti and Micozzi 2014) or how cosponsorship reflects provincial and municipal-level ambitions in the Argentine congress (Micozzi 2014). Case studies have relayed novel findings but have maintained variance mainly at the institutional level. Given institutional fragility in Latin America, individual, party, and subnational dynamics actually confer more information (Luna 2007). This article aims at advancing this approach.

This article provides a framework to analyze the individual determinants of ambition based on two assumptions. First, it assumes that legislators' retrospective and prospective loyalty and previous career paths have a party- versus personal-centered character. Second, it assumes that these differences facilitate access to different offices within a context of interparty competition. Based on these assumptions, the article finds links between office goals, party- versus personal-centered career paths, and how legislators react to the level of competition in their environment from a cross-national perspective. The article proceeds as follows: First, it discusses a theoretical framework for conceptualizing the rational politician and ambition theory. Second, it discusses different types of ambitions and discusses extant work on Latin America. Third, it discusses the dependent variable and intervening factors in a politician's decision to seek a certain office. Fourth, it presents the data and the model used in the analysis. Last, it discusses the results and shows that party competition and party- versus personal-centered career paths affect different office goals.

\section{Which Ambition?}

Schlesinger (1966) defines three types of ambition: (1) static, (2) progressive, and (3) discrete ambitions: reelection, moving on to other offices, or leaving office, respectively. Herrick and Moore (1993) add the intrainstitutional category and criticize Schlesinger's focus on offices rather than positions in congress. Another category based on the Brazilian experience underscores dynamic (Samuels 2003) or regressive (Leoni, Pereira and Rennó 2004) ambition. Here, the legislature is not an ultimate goal but rather a stepping-stone in a longer career outside of the legislature, which leads to a central point brought up by Rohde (1979): most legislators harbor progressive ambition, but it depends on the risks an individual is willing to take at a certain point in time. Theory has mainly focused on the causes and consequences of ambition. Research on the causes of ambition explores the effects of legislative resources on ambition (Maestas 2000), or the determinants of the initial decision of running for office (Fox and Lawless 2005).

Studies on the consequences of ambitions focus on how legislators' ambitions influence partisan tides (Jacobsen 1989), lead to a heightened focus on constituencies and public opinion (Maestas 2003), and help garner support in attaining policy goals (Herrick and Thomas 2005; Meserve, Pemstein and Bernhard 2009). In the same vein of research, studies also explain how ambitions lead to cosponsorship of certain bills (Crisp 
and Botero 2004; Micozzi 2014) or increased levels of specialization (Victor 2011). The main interest in both veins of research lies in distinguishing how behavior and preferences influence one another; the relationship is therefore cyclical (Black 1972) and thus can be examined from both perspectives. Political careers in Latin America don't follow the US model where all roads lead to a long career in Congress (Botero 2008; Botero and Renno 2007). They inevitably deviate from the US pattern where reelection is limited (Carey 1998) or in multilevel settings (Jones 2002; Langston 2011; Leoni, Pereira and Rennó 2004; Lodola 2009; Samuels 2003, 2011). For instance, Brazilian legislators prefer office in the regional executive branch (Samuels 2003, 2011). Similarly, Mexican legislators begin their careers on the municipal and state levels and respond strongly to regional governors in light of possible future careers in the states (Langston 2011). Even unitary settings show that regional offices (Chasquetti 2010; Chasquetti and Micozzi 2014), the national executive (Taylor 1992), or reelection (Botero 2008) offer attractive incentives. Reelection-seekers can also end up making "unorthodox" moves due to party competition (Botero 2008).

\section{What's in It for Me? Evaluating Advantages of Different Offices}

Legislators are constantly evaluating their goals. Regarding specific goals such as policy, office, or votes in mind (Müller and Strom 1999), they should strive towards maximizing their benefit based on which options are most "available, accessible, and attractive" (Borchert 2011). Politicians examine alternatives in terms of which alternative yields the greatest expected value (which may not always be the "correct" choice). The decision is thus based on the costs, benefits, and probabilities that operate at the time of their stated preference rather than other factors based in their childhood or elsewhere (Black 1972). What are the costs of moving on, and what utilities do different alternatives offer? Next, when is the right moment to move on (Maestas et al. 2006)? Parties are inevitable protagonists in a legislator's career (Müller 2000). The party plays an important role at various stages and can constitute the link in a politician's career. In an early gatekeeping stage, parties try to recruit loyal partisans. In a later stage, they control access to the party lists, and after elections, they distribute leadership positions in the house such as committee chairmanships or chamber leaders and provide support for higher positions such as the presidency or ministries. The party's influence should be evident in a legislator's career path; loyal partisans should rely on the party as their main principal, while others might rely on voters to a greater extent. Legislators with their own agenda might distinguish themselves by relying on their own visibility or reputation in order to be elected. Progressively ambitious legislators need to increase their visibility and their own reputations if they are planning on moving "up" in their political career.

\section{Progressing in Which Direction?}

The value of each office clearly varies in each country, making it impossible to create a hierarchical scale generalizable enough to fit all countries. Instead, it is useful to examine benefits associated with different offices that can be associated with term limits, reelection, or advancement options, reputation-enhancement possibilities, policy influence, access to resources, or "risk-taking" (Rohde 1979). Though career possibilities vary in their weight and value across countries, the main categories of progressive ambition exist in all 14 countries analyzed, except for the senate ${ }^{1}$ in unicameral countries: president, national executive, reelection, regional executive, and mayor. Table 1 displays general characteristics of each office in Borchert's (2011) terminology regarding the accessibility, availability, and attractiveness of each office. ${ }^{2}$

While the value of offices varies in each political system, similarities can be drawn based on the level and the type of office. On the national level, the senate is the more prestigious option within the legislative branch, while the national executive is perhaps the most prestigious option besides the presidency. The national executive is especially symbolic as the link between the president and the legislature and differs from all other elected offices in that it is an appointed office. This office requires a good reputation within the party and demands more experienced politicians. Consequently, specific constituencies and regional issues decrease in importance as party reputation and good favor among party leaders become more important. On the local or regional level, mayoralty and the regional executive branch offer attractive options. Both 


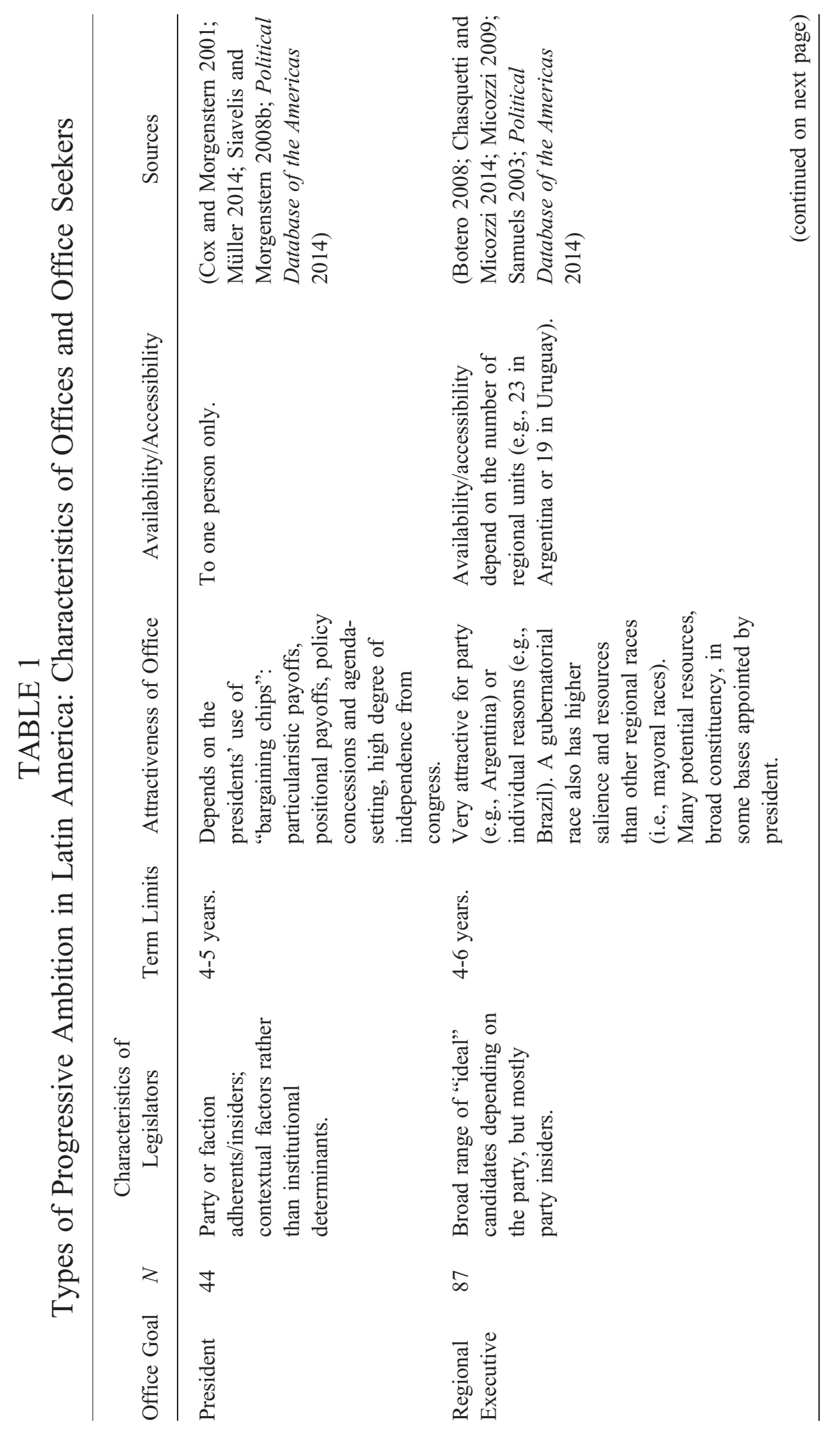




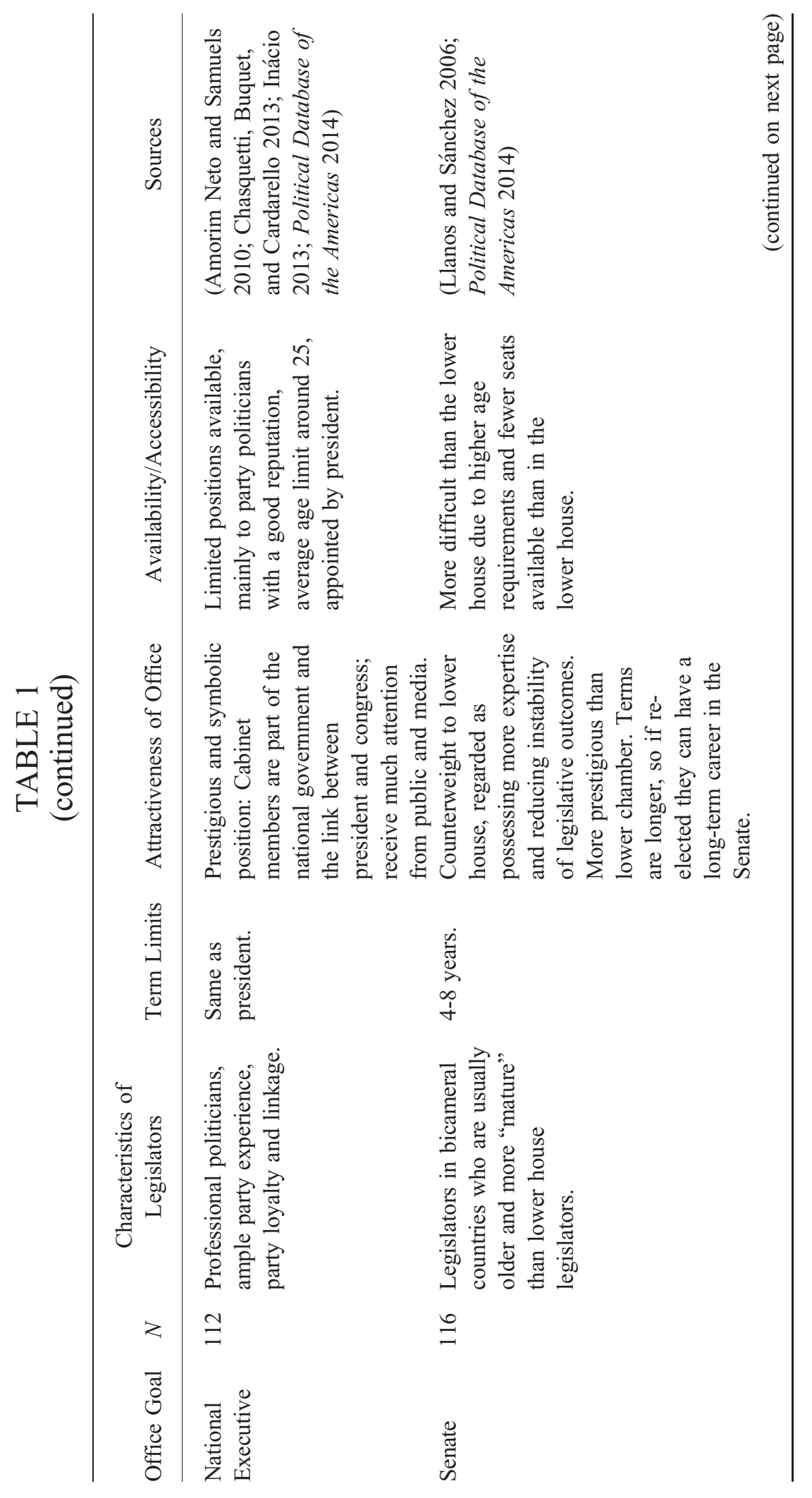




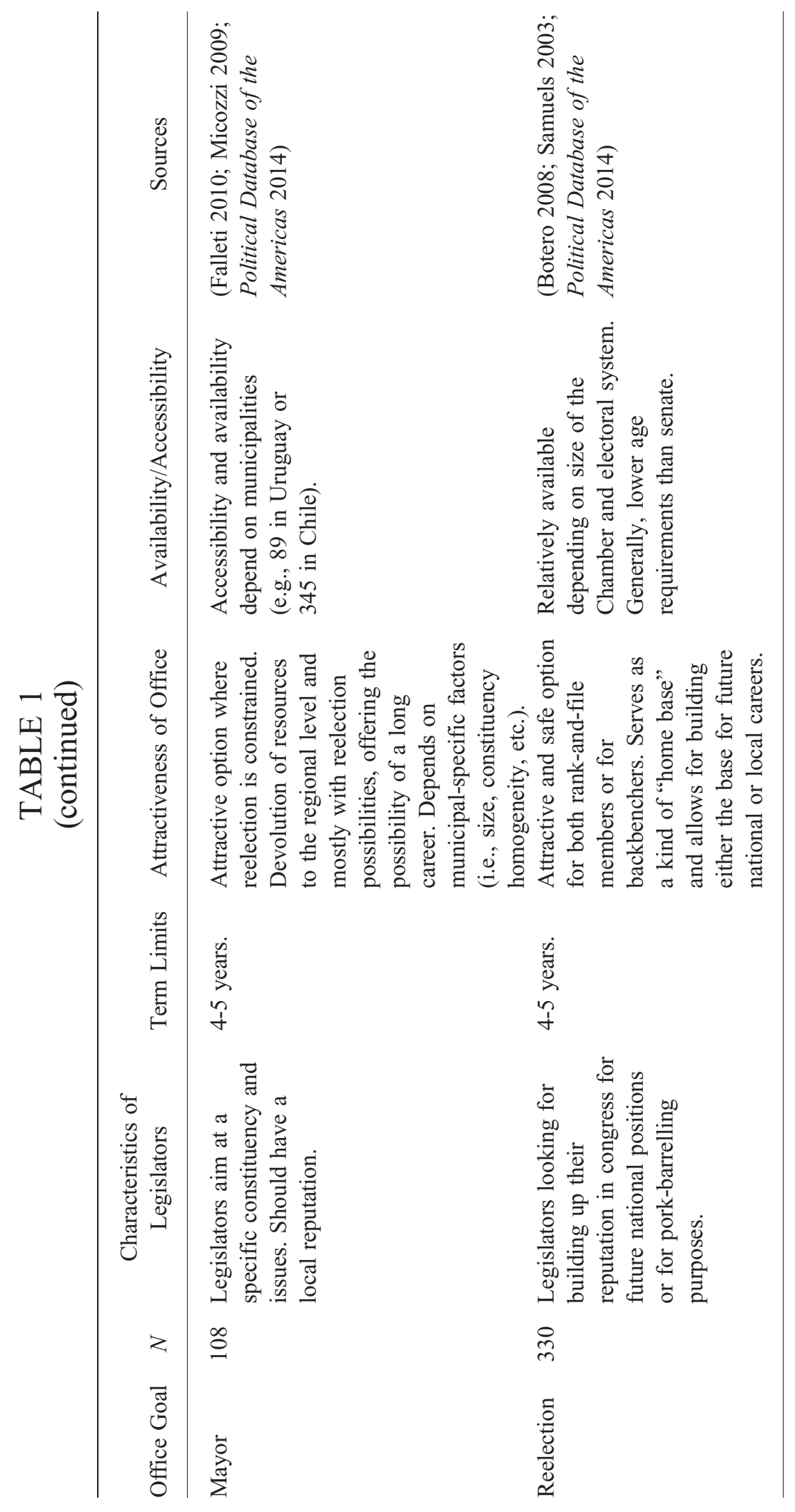


imply reliance on more specific constituencies and issues that must be addressed in their campaigns on the regional level, thus differing substantially from the national party line. Like the national executive branch, some offices in the regional executive branch are appointed ones. In sum, those seeking local or regional offices should thus not move too far away from the local/regional constituencies/actors they aim to target after their legislative period is over.

\section{Explaining Different Dimensions of Progressive Ambition}

I define "progressive ambition" in line with Samuels (2003) as a politician's desire to build a political career outside of the chamber of deputies. A deputy possessing progressive ambition is one who seeks or wins an appointed or elected position in the municipal or federal government or as president after the current period in the chamber. Next, I group the independent variables into two categories that distinguish between personal- and party-centered elements. The first group covers why they got elected and who they focus on in their legislative activities. It encompasses how defending the actors that supported legislators in their election (retrospective loyalty) and the extent to which their constituency plays a role in their current legislative work (prospective loyalty) and shapes future office goals (Martínez Rosón 2011). The second group includes three indicators from their previous career path and their ideological left-right placement. Finally, I include three nonindividual contextual variables related to the competition dynamics: national competition, regional competition, and district magnitude. This section examines these variables that lead to differing ambitions and puts forth various hypotheses that refer either to specific posts sought or the general type of ambition (static or progressive). Let's begin with the electoral connection.

\section{District Magnitude}

Electoral systems have early on been recognized to influence legislative careers (Mayhew 1974); this impulse comes from the reelection goal and the "personal vote" and heightened constituency service (Cain, Ferejohn and Fiorina 1987). It has been well established that different features of electoral systems such as district magnitude, ballot structure, or the interaction of both (Carey and Shugart 1995) can have an impact on legislative behavior. Here I focus on district magnitude since this is generally considered the most powerful predictor. In closed-list systems, an increase in district magnitude leads to a decrease in the importance of individual candidates' qualities; parties are more central in determining a candidate's fate. In open-list systems, the value of personal reputation might increase as district size does, but it doesn't ultimately increase links to constituents (Siavelis and Morgenstern 2008a). Regarding ambition, district magnitude should matter insofar as the extent to which candidates depend on party leaders. I would assume that legislators are more likely to harbor progressive ambition in larger districts; the pool of candidates is larger and therefore the chances of being elected are smaller given the increased number of candidates. In smaller districts where the personal vote is more widespread, candidates depend more on their experience, their campaign, and their constituents, and they have the chance to cultivate their own reputation. This leads to the assumption that in smaller districts where the pool of candidates is lower, legislators have less incentive to go somewhere else and might have a stronger link with constituencies that provides more incentives (e.g., pork-barreling) for aiming at reelection.

$\mathrm{H} 1$ : As district magnitude increases, legislators are more likely to harbor progressive ambition.

\section{Interparty Competition}

Differing distributions of party strength and differing electoral bases should affect the availability of offices to ambitious legislators (Schlesinger 1966, p.130). Competitive constituencies are likely to converge, while divergent constituencies are likely to diverge. As competition between parties decreases, the more similar the career lines and opportunities should be. Along these lines, less competition makes legislators strive for reelection (Botero 2008) or higher offices (Samuels 2003), while a high level of competition forces legislators to look beyond the legislature (Botero 2008). However, party competition can play out very differently on the national and the regional level. Schlesinger's findings (1966) showed that differences in party competition 
between state-affected careers and parties at the national level. Further research (Black 1972) found that the degree of competition in local elections affected politicians' risks and investment required to win office and that only those expecting large benefits will run for office in large, competitive districts. In sum, regional and national dynamics provide two realms of competition; if one becomes too competitive, the other realm should become more attractive.

H2: Increased national party competition should lead to regional-level office goals, while increased regional party competition should lead to national-level office goals.

\section{Who Got You There and Who Will Get You Further? Retrospective and Prospective Loyalty}

The previous hypotheses encompass the dynamics of national and regional party competition. The next hypotheses go directly to the individual level. Determining career paths requires identifying to whom politicians owe loyalty; different loyalties yield different types of candidates (Siavelis and Morgenstern 2008b). In the United States, senators with more party loyalty are more likely to seek higher offices than those who don't (Treul 2009). If a party is responsible for electoral success, legislators should retrospectively defend their leader's image or their party's program or ideology. If they were rather elected based on their own success in office, personal sympathy, or their campaign, legislators can use their own reputation in seeking another office.

H3a: Legislators' retrospective loyalty towards the party should lead to progressive ambition for national executive and senate offices.

As an indicator for prospective loyalty, I draw on one main variable: the degree to which legislators focus on their constituency while in office. Legislators who are visible in the public eye and maintain close constituency contact most likely depend on their voters for reelection or might see constituents as key supporters if they aim at returning to the local level. National-level politics still play a role in determining or appointing regional executive positions in some cases, so the constituency shouldn't be as crucial here as in reelection. The more legislators claim to focus on their constituency, the more important they should be in seeking reelection or regional office.

$\mathrm{H} 3 \mathrm{~b}$ : Increased prospective loyalty toward the constituency should lead to ambition for reelection or regional offices.

\section{Previous Political Experience}

Some studies underscore the relevance of incumbency in adopting certain orientations (Bell and Price 1969; Black 1972). Particularly, prelegislative political experience is what determines certain roles much more than other nonpolitical occupations (Bell and Price 1969). I include incumbency in addition to previous offices. Incumbents have already been reelected to the house, meaning they see some benefit in staying there. I argue that legislators aiming at regional positions won't spend too much time away from their constituencies, which is what the Brazilian or Argentine cases have shown. If legislators have been reelected, it means they see incentives in congress and might use those as an opportunity to build up their reputation before moving to other offices on the national level.

H4a: Incumbents are more likely to aim for other national-level offices.

Party office, (i.e., party leader, parliamentary party leadership, or front-bench status-any position where the party is in control) is one of the types of office that legislators might seek compared to legislative office, which is non- or cross-partisan in nature (Strøm 1997). Party office in this case can be an incentive for reelection as it provides status in the house and establishes a hierarchy, distinguishing front- from backbenchers. Party office thus creates incentives to stay in the house and coordinate with party bases or the party outside of congress. It should thus be expected that legislators having occupied important party positions should seek reelection. 
H4b: Legislators who have held previous party office should harbor static ambition.

The distinction between elected versus appointed office can also have implications for party and personal representation. Voting procedures emphasizing the candidates over their parties should emphasize personal over party representation (Colomer 2011). Previous elected office should lead to some degree of public visibility leading to a more personal style of representation since it implies leading a campaign and building a reputation in order to get elected.

H4c: Legislators who have held previous elected offices should harbor progressive ambition for offices with heightened focus on personal reputation and campaign (e.g., mayor, senator).

Next, appointed office (i.e., minister or vice-minister) signify loyalty and respect from other party members and is associated with party representation in general (Colomer 2011). Thus, it could be expected that appointed offices should lead to progressive ambition where reputation in the party can be an asset for attaining offices. This would imply that party support is there, while additionally having built one's own reputation.

H4d: Previous appointed office should lead to office goals for which party reputation and experience are relevant (national and regional executive, presidency, senate).

Finally, I control for ideology. Party ideology has played a role in behavior such as party switching (Desposato 2006) since different ideologies prompt legislators to switch or stay in the most compatible party. Regarding ambition, research in the United States shows that liberal republicans and conservative democratic state legislators are less likely to run for Congress than those at the ideological poles (Thomsen 2014). Other findings show that in Brazil, leftist legislators are more distant from winning outcomes and derive less utility from staying in a certain office, while leftist party structure and size also matter (Leoni, Pereira and Rennó 2004). Arguing that ideology influences career strategies is nonetheless a risky endeavor; different career options should be attractive to any legislator regardless of their left-right placement. I thus do not posit a hypothesis regarding this variable, but rather I include the legislators' left-right placement as a control variable.

\section{Data and Methods}

I draw on survey data from the University of Salamanca. The Latin American Parliamentary Elite Project (Alcántara Sáez 1994-2014) carries out surveys in 18 Latin American countries at the beginning of each legislative period. In bicameral legislatures, only the lower house is surveyed. Given its anonymity, survey data can relay important information on preferences that behavioral data (i.e., actual offices held) does not confer. Survey responses are thus a more valid indicator of ambition than behavioral proxies (Sieberer and Muller 2015). I use the most recent surveys from 14 legislatures, while drawing on descriptive data from the most recent wave from each country which was the legislative period between 2006 and 2012. Table 2 displays a sample description by country. The sample is limited to the most recent waves due to the availability of survey question on office goals. The question is phrased as follows: "After your current office, what would you like your next office to be?" The dependent variable is divided into six categories. ${ }^{3}$ The six stated ambitions included here differ enough from one another so that none of the dimensions have to be combined. ${ }^{4}$ This means that in a legislators' mind, each office is of distinctive value and clearly presents different advantages.

Figure 1 shows the distribution of responses by country. The base category is reelection; an exception here is Mexico and Costa Rica, where consecutive reelection is constrained. ${ }^{5}$ In other bicameral legislatures, the senate also seems to be an attractive next step, especially in Chile, Colombia, Mexico, and Paraguay. The same goes for the national executive; $43 \%$ of Costa Rican legislators seek a national executive office, while the share in Paraguay is $2 \%$. The regional executive is most attractive in Ecuador, Argentina, or Colombia 


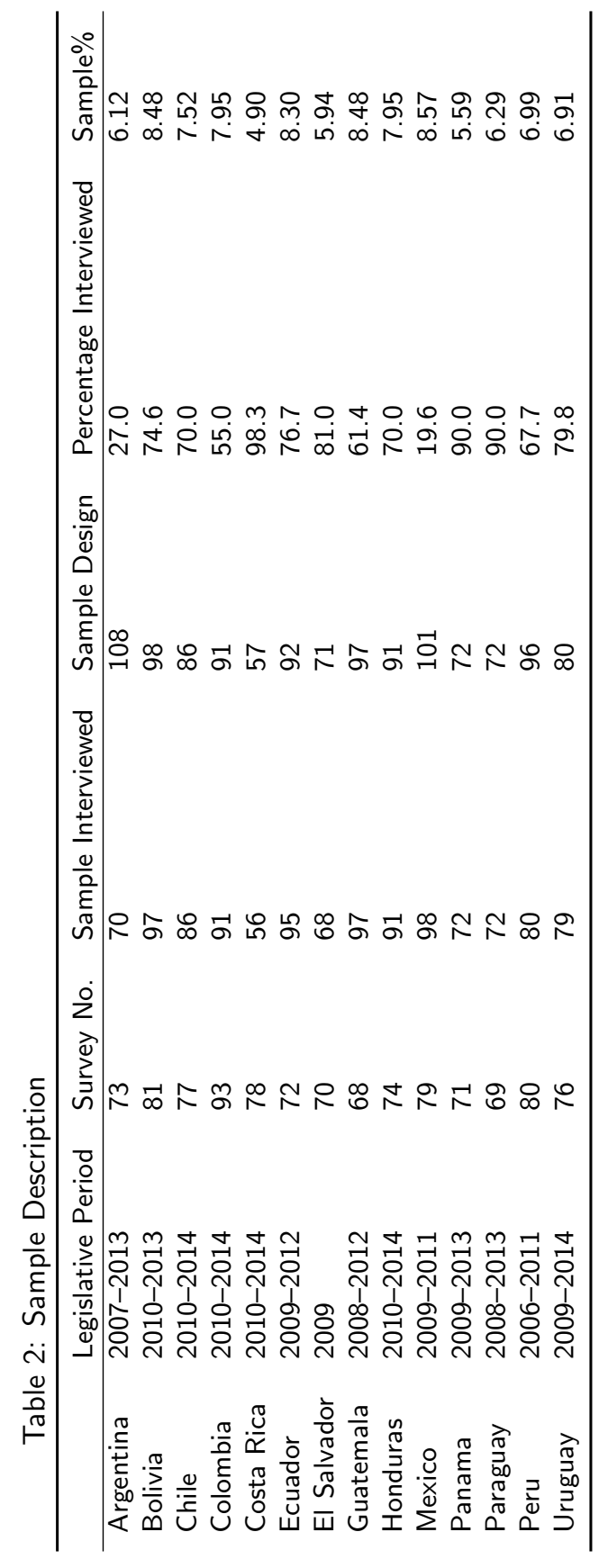




\section{Figure 1: Shares of Legislators' Office Goals in Latin America Based on PELA Data (2006-2012)}
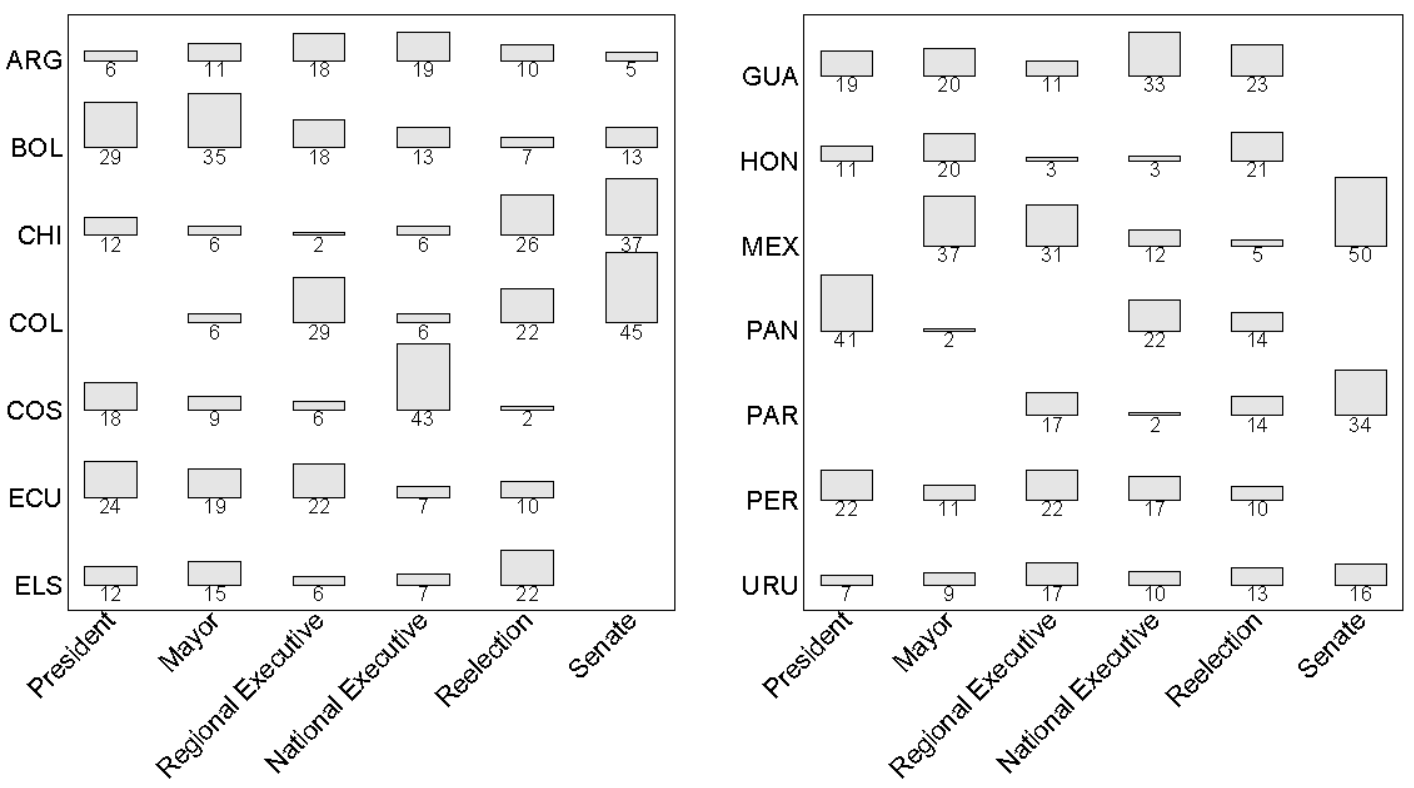

and is less attractive in Chile, El Salvador, or Honduras. Mayoralty is another attractive position. Here, Bolivia and Mexico have the highest shares, while in Colombia or Chile, mayoralty is less attractive. Last, presidency represents the most far-fetched option. Nonetheless, Panama (41\%) and Bolivia (29\%) have the highest shares.

The categorical nature of the dependent variable requires a multinomial regression analysis to test the hypotheses. This allows comparing between categories rather than one category versus all other categories in a simple binary approach (Long and Freese 2006). In multinomial models, the basic assumption is that the legislators will choose the alternative that provides higher utility than all other options: in this case, attractiveness of different offices as distinct options. The omitted category is referred to as the base category, and all parameters' estimates of the model are relative to the base category. Here, the base category is reelection since it is the most frequent alternative chosen, so the regression results for each outcome are relative to reelection. I run a single-level model with robust standard errors. ${ }^{6}$ The model includes continuous and dichotomous predictor variables.

To measure party competition, I take the difference between the party with the most votes and the runner-up (Carsey et al. 2008). This logged difference is my indicator of party competition and has been collected on both the regional and national level. The remaining variables are treated as follows: district magnitude, left-right placement, and constituency importance (prospective loyalty) are logged in order to be scaled similarly to party competition. Incumbency, previous office, and prospective loyalty variables are coded as dummies. ${ }^{7}$

\section{Analysis}

Instead of presenting regression tables, I show the significant effects of the covariates on the predicted probability of choosing a certain office (see the Appendix for regression results). The most significant results are displayed in Figures 2, 3, and 4. Figure 2 presents the predictive margins of national and regional 


\section{Figure 2: The Effect of Party Competition on Ambition \\ Predictive Margins with $95 \%$ Confidence Intervals}
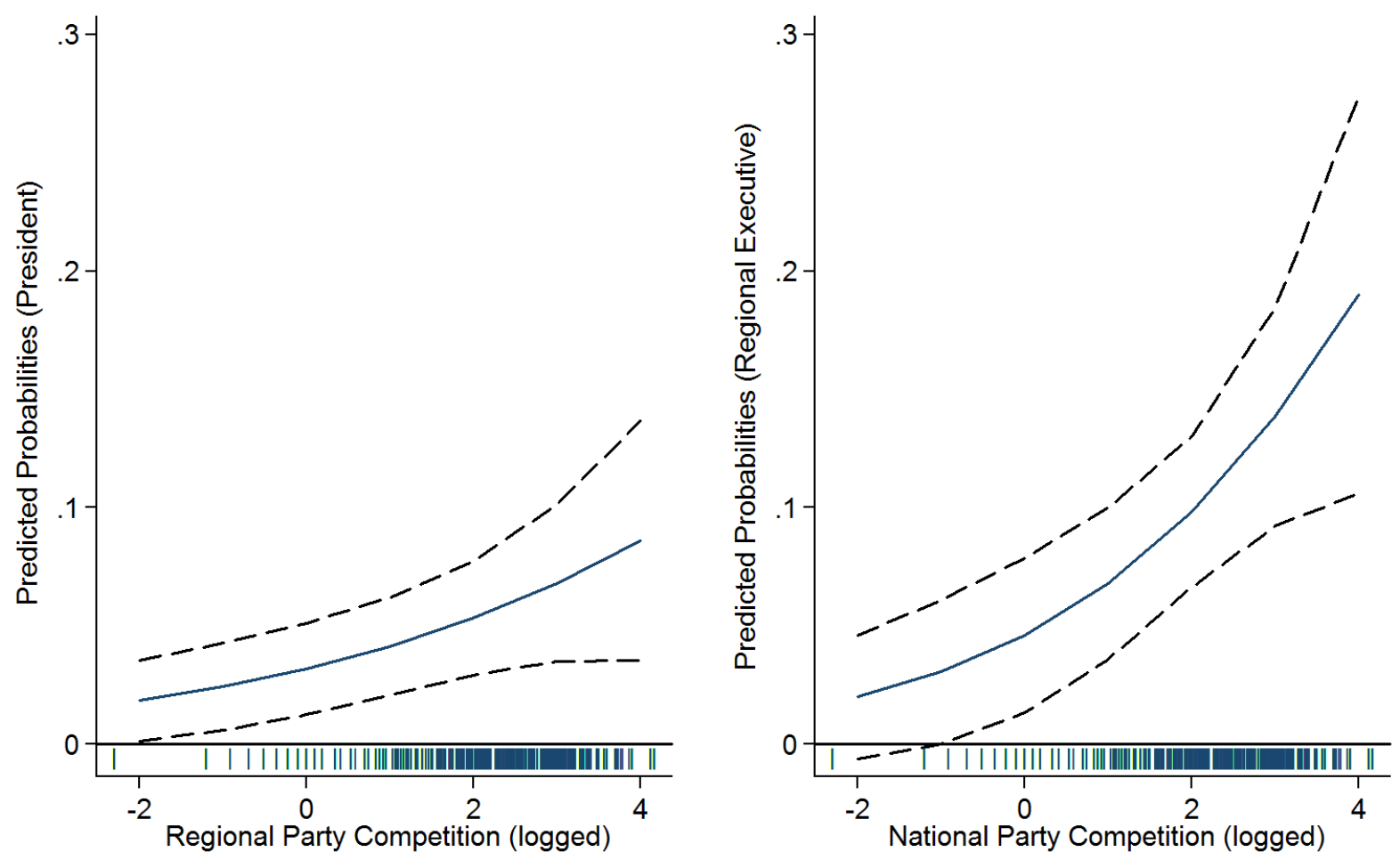

competition on choosing a certain office. These show the predicted probabilities ( $y$-axis) for different levels of regional and national party competition (x-axis) and the distribution of regional and national competition at the bottom of the figure. Here, an increase in regional and national party competition leads to an increased probability of aiming for the presidency and regional executive, respectively. Specifically, the change in probability of aiming for presidency versus reelection between the minimum and maximum value of regional party competition increases by $7 \%$. Conversely, the change in probability of aiming for regional executive office compared to reelection between the minimum and maximum value of national party competition increases by $11 \%$. Both the effects of regional and national party competition provide partial evidence for Hypothesis 2, however, only for the two mentioned offices. The results thus partially show that legislators do indeed seem to be progressively ambitious for offices on the level where competition is less fierce.

Figure 3 summarizes the extent to which a legislator's party versus personal-centered career and their retrospective loyalty influence the kind of offices they seek by showing the predicted probabilities for each variable. Regarding retrospective loyalty, legislators who claim to owe their election to party versus personal reasons are much more likely to stay in congress by seeking reelection or moving to the senate. The only difference here is that loyalty towards the party ideology is more important for moving on to the senate compared to reelection. Here, the predicted probability of choosing the senate increases by $17 \%$ if legislators owe their election to the party ideology. Owing an election to the party leader's image or to the party program decreases the probability of seeking elected offices such as the presidency (by $4 \%$ and $3 \%$, respectively) and mayor (by $2 \%$ and $10 \%$, respectively) compared to reelection. A similar effect is observed for regional executives regarding the leader's image and party ideology. In sum, legislators with progressive ambition mainly draw on their personal resources rather than party factors such as the leader image or the party program; they rather emphasize their personal experience in the legislature or other posts ( $\mathrm{H} 3 \mathrm{a})$. 


\section{Figure 3: The Effect of Experience and Loyalty on Ambition}

Average Marginal Effects with $95 \%$ Confidence Intervals

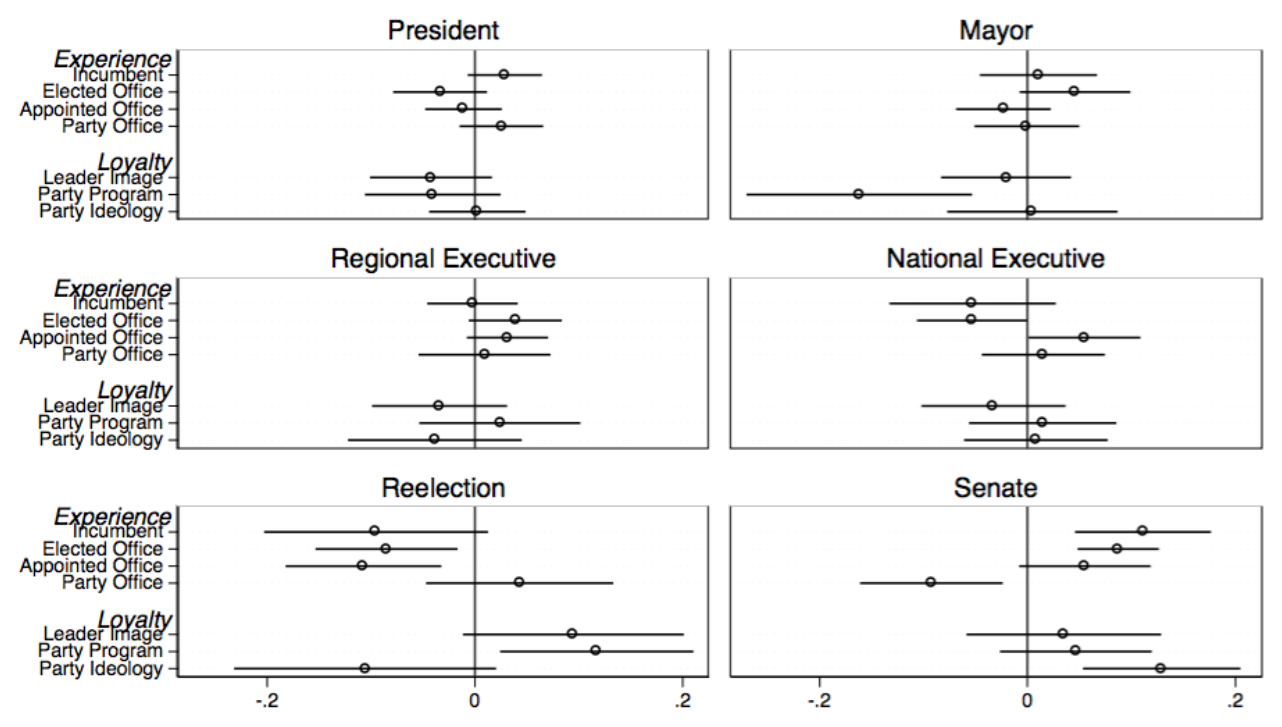

Moving on to prospective loyalty, the results showed that its effect was negative for all outcomes compared to reelection (more constituency focus for reelection seekers); however, this effect was not significant. Thus, the results do not provide evidence for Hypothesis 3b.

Previous career paths matter for all offices, but as expected, different types of experience matter for some offices more than others. In line with Hypothesis 4a, incumbents seek offices on the national level, especially in the senate. Here, the probability of choosing the senate rather than reelection for incumbents increases by $23 \%$ compared to newcomers. Those having held party office indeed appear more likely to harbor static ambition. The probability of seeking reelection versus all other offices increases by $43 \%$ for those with previous party office compared to those without previous party office. This provides evidence for Hypothesis $4 \mathrm{~b}$ which posited that party office provides incentives to stay in the lower chamber. Previous elected office increases the likelihood of seeking mayor, regional executive, and senate offices compared to reelection. The probability here increases by $16 \%, 14 \%$, and $20 \%$ for each of these offices, respectively, compared to legislators with no previous elected office. This provides partial evidence for Hypothesis 4c that posited that elected offices lead to progressive ambition for offices that imply a personal reputation and campaign. This effect goes in the negative direction for presidency, national executive, and reelection.

Appointed office increases the probability of aiming at both types of executive offices and the senate compared to reelection ( $12 \%$ for regional executive and $18 \%$ for national executive office and the senate). In other words, previous-appointed offices are relevant for future appointed ones (cabinet positions in the executive branch are always appointed; a regional executive is in some cases) or for the senate where the more experienced party politicians go.

The most robust effect is the effect of legislators' left-right placement on their office goals. The effect is significant for all categories compared to reelection. I plot the effects for two categories to show the contrast between reelection (the base category) and regional executive (representing the effect for all other categories). Again, the distribution of the variable is displayed at the bottom of the figure. Figure 4 shows that as a legislator's ideological position moves to the right, the probability of choosing reelection increases. In other words, the change in probability of choosing reelection between the minimum and maximum values of the left-right scale increases by $68 \%$. The opposite occurs for regional executive office; a move to the right on the ideological scale decreases the probability of choosing the regional executive office compared to 
Figure 4: The Effect of Left-Right Placement on Ambition

Predictive Margins with $95 \%$ Confidence Intervals
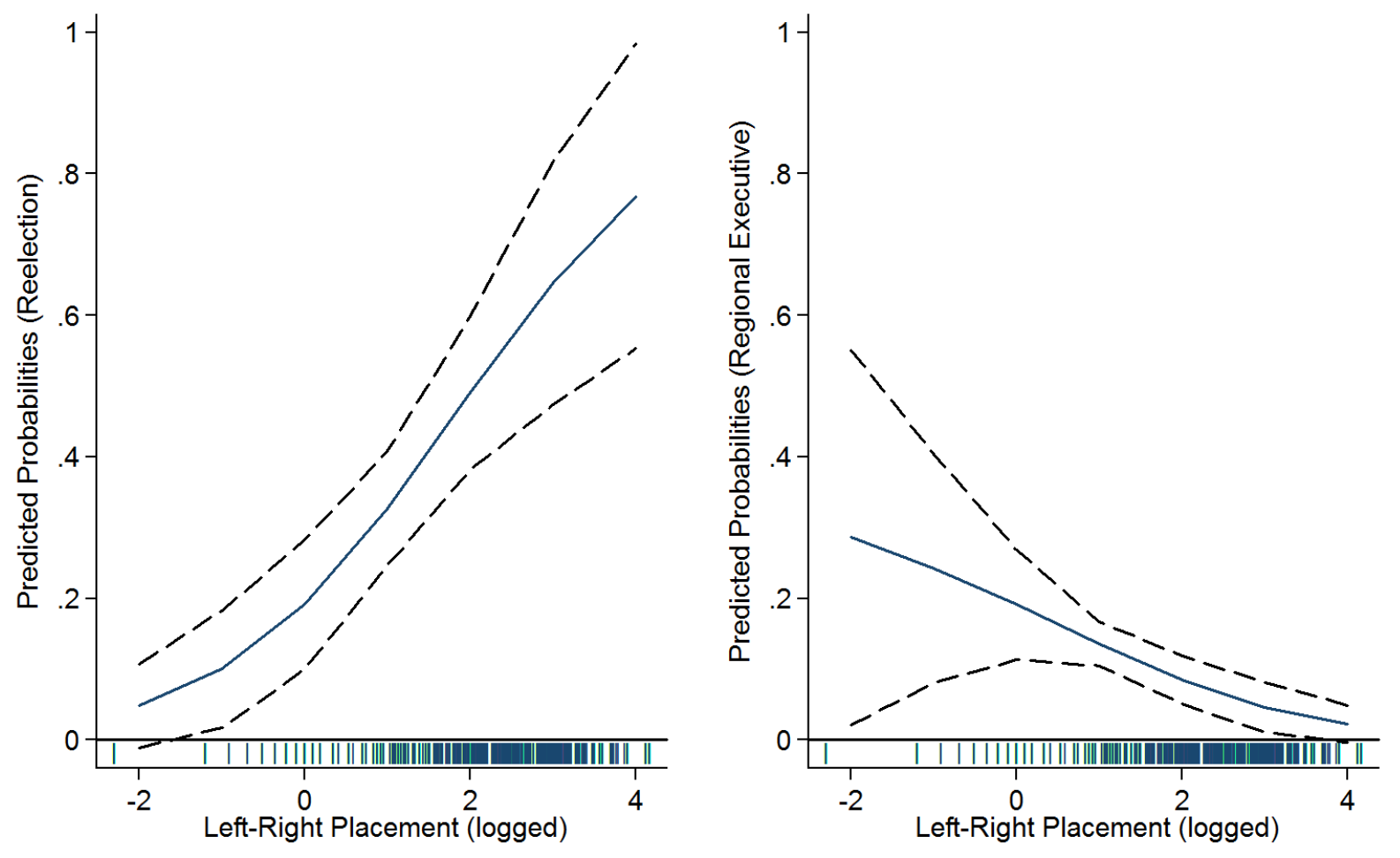

reelection. Here, the change in probability for choosing regional executive office between the minimum and maximum values of the left-right scale decreases by $24 \%$. Thus, ideological conservative legislators tend to seek reelection versus seeking other offices. 
Table 3: Summarized Results

\begin{tabular}{llll}
\hline Hypothesis & Independent Variable & Expected Relationship & Observed Relationship \\
\hline $\mathrm{H} 1$ & District Magnitude & + & 0 \\
$\mathrm{H} 2$ & Party competition & + & $/$ \\
$\mathrm{H} 3 \mathrm{a}$ & Retrospective loyalty & + & + \\
$\mathrm{H} 3 \mathrm{~b}$ & Prospective loyalty & + & 0 \\
$\mathrm{H} 4 \mathrm{a}$ & Incumbency & + & + \\
$\mathrm{H} 4 \mathrm{~b}$ & Party office & + & 0 \\
$\mathrm{H} 4 \mathrm{c}$ & Elected office & + & + \\
$\mathrm{H} 4 \mathrm{~d}$ & Appointed office & + & + \\
Control & Left-right placement & 0 & + \\
\hline
\end{tabular}

Overall, I find full or partial support regarding some of the hypotheses. The effects of district magnitude and prospective loyalty are not significant for any category of ambition. Thus, Hypothesis 1 and Hypothesis $3 b$ could not be confirmed. The expectations regarding party competition $(\mathrm{H} 2)$ was only partially confirmed, while strong evidence is found for the expected effects of retrospective loyalty ( $\mathrm{H} 3 \mathrm{a})$, incumbency $(\mathrm{H} 4 \mathrm{a})$, previous office $(\mathrm{H} 4 \mathrm{~b}-\mathrm{H} 4 \mathrm{~d})$, and ideology. Table 3 outlines the results.

\section{Conclusion}

The goal of this article was to analyze legislator's ambition by deviating from country-level generalizations and contributing to the discussion on individual determinants of ambition. The article has provided a first cross-national approach by mapping out progressive ambition based on legislators' career paths and loyalty in a context of party competition. The results provide some evidence that national party competition leads to progressive ambition at the regional level (the regional executive branch), while regional competition leads to national-level ambitions (presidency). This only partially confirms the assumption that legislators analyze their chances and aim for positions where competition is less fierce since the model doesn't provide evidence for all offices. Results are also clear in that the extent each office relies on party resources-the party leader's image, the party program, or the party ideology-vary. The most retrospectively loyal partisans appear to have more static ambition than their progressively ambitious counterparts; this goes for reelection and senator office seekers.

Experience is most likely crucial for every office, but following previous findings, it is the type that matters. Incumbents tend to strive for national-level offices such as the presidency and senate, while elected office experience proves to be crucial for regional offices and also for the senate. Appointed office appears to be a prerequisite for national executive, regional executive (possibly where these offices are still appointed), and the senate. Party office is significantly less important for the senate than reelection. The senate seems to be a goal for legislators who have occupied all of these offices, confirming the findings on the prestige of the senate and the importance of policy (i.e., party ideology) compared to the lower chamber. Especially those aiming for the presidency or mayoralty are less likely to draw on the leader's image or the party program as a resource compared to reelection. This provides evidence that personal resources might be more relevant for offices implying a personal-centered campaign.

While country specifics are not discussed at length, the purpose is to get a general overview by carrying out the first larger cross-national comparison on ambitions. The article proposed various hypotheses, arguing that a more personal- versus party-profile examined from a different perspective does indeed lead to increased progressive ambition. In other words, who a legislator responds to concretely influences their goals. The results emphasize that studies should focus on the type of progressive ambitions given the heterogeneity of the latter. This article shows that progressively ambitious legislators must go beyond party resources to attain their future goals outside of the chamber, and this will make all the difference in their future career. 
This article makes an important and novel contribution for various reasons. First, it is the first quantitative comparative analysis regarding ambition in Latin America across 14 countries. It focuses on understanding ambitions and provides a first cross-national overview of the individual determinants of office goals. Second, it provides a new understanding of progressive ambition in Latin America. It describes not only what offices legislators in isolated institutional environments strive for, but rather it unveils the nature of ambitions in light of party- versus personal-centered career paths and party competition. Third, it marks a new direction in Latin American legislative politics within political science. Until now, scholars have mainly focused on showing how different ambitions in Latin America are from the US context where static ambitions prevail. We now have rich empirical material that allows going beyond this distinction by distinguishing and explaining progressive ambition in Latin America. Last, it underscores the importance of focusing on individual data rather than institutional variation. This has implications for Latin American legislative studies in diverting the focus to how individuals and parties work within different institutional frameworks. This article is a first approach in this direction, but it is only a start. A next major step would imply focusing on a scale that takes the varying value of offices into account, examining the effects of parties, and looking at the actual implications of ambitions in the policymaking process and outcomes.

Appendix: Multinomial Logit

\begin{tabular}{|c|c|c|c|c|c|}
\hline \multicolumn{6}{|c|}{ Why Legislators Choose Reelection Versus Other Offices in a Single-Level Multinomial Regression } \\
\hline & \multicolumn{4}{|c|}{ District magnitude and competition } & Senate \\
\hline Regional competition & $.32(.14)^{*}$ & $.07(.11)$ & $-.07(.11)$ & $.17(.13)$ & $.14(.13)$ \\
\hline National competition & $.02(.13)$ & $.11(.13)$ & $.41(.14)^{* * *}$ & $.07(.11)$ & $-.21(.12)$ \\
\hline District size & $.14(.22)$ & $-.13(.20)$ & $-.23(.15)^{* *}$ & $-.07(.10)$ & $.14(.12)$ \\
\hline \multicolumn{6}{|l|}{ Retrospective loyalty } \\
\hline Leader image & $-1.1(.58)^{*}$ & $-.43(.33)$ & $-.65(.37)$ & $-.54(.35)$ & $-.05(.44)$ \\
\hline Party program & $-1.1(.65)$ & $-1.6(.44)^{* * *}$ & $-.12(.44)$ & $-.23(.32)$ & $-.01(.34)$ \\
\hline Party ideology & $.33(.48)$ & $.06(.53)$ & $.06(.53)$ & $.35(.34)$ & $1.3(.40)$ \\
\hline \multicolumn{6}{|l|}{ Prospective Loyalty } \\
\hline Constituency importance & $-.67(.45)$ & $-.16(.44)$ & $-.02(.80)$ & $-.02(.80)$ & $-.43(.44)$ \\
\hline \multicolumn{6}{|l|}{ Previous career path } \\
\hline Appointed office & $-.03(.37)$ & $.11(.24)$ & $.65(.27)^{*}$ & $.65(.27)^{* *}$ & $.65(.29)^{* *}$ \\
\hline Elected office & $-.39(.45)$ & $.62(.26)^{* *}$ & $.61(.26)^{* *}$ & $-.17(.25)$ & $-.88(.19)^{* * *}$ \\
\hline Party office & $.36(.45)$ & $-.11(.27)$ & $-.00(.36)$ & $-.03(.29)$ & $-.77(.34)$ \\
\hline Incumbent & $.72(.36)^{* * *}$ & $.35(.31)$ & $.19(.31)$ & $-.16(.39)$ & $1.0(.37)^{* * *}$ \\
\hline \multicolumn{6}{|l|}{ Control } \\
\hline Left-right placement & $-.61(.32)^{* *}$ & $-.88(.31)^{* * *}$ & $-.93(.21)^{* * *}$ & $-.77(.25)^{* * *}$ & $-.41(.38)$ \\
\hline Constant & $-1.4(.93)$ & $-.42(.75)$ & $-.11(.64)$ & $-.02(.80)$ & $-.66(.86)$ \\
\hline McFaddens R & .07 & & & & \\
\hline Log likelihood & -1121.6 & & & & \\
\hline $\mathrm{N}$ & 757 & & & & \\
\hline
\end{tabular}

Note: The table displays estimates and standard errors in parentheses. ${ }^{*} \mathrm{p} \leq 0.10,{ }^{* *} \mathrm{p} \leq 0.05,{ }^{* * *} \mathrm{p} \leq 0.01$. Reelection is the base category. 


\section{NOTES}

${ }^{1}$ For the empirical analysis, I tried excluding the senate category to see if it led to biased results. Since this was not the case, I included it.

${ }^{2}$ Clearly, the table provides only a general overview and a snapshot of each office across countries. However, even if I included a scale of desirability, this might disregard the value that the individual assigns to each office. I thus leave it as such.

3 I exclude "Don't knows" and "No answers" and three further categories with low response rates: an office in a stateowned company (four responses), an office in the private sector (nine responses), and "another office" (47 responses). While the last category has a substantial number of responses, the structure of the survey question does not allow for specification, therefore creating a very vague dimension of ambition. After excluding these categories, the $\mathrm{N}$ is reduced to 757 legislators in the regression.

${ }^{4}$ This is confirmed through the mlogtest in Stata, the purpose of which is to test whether any pair of outcome categories can be combined.

${ }^{5} \mathrm{~A}$ recent reform has changed this rule in Mexico, but for the time period included in this article, the rule was still in place.

${ }^{6}$ Given the hierarchical structure of the data, I ran single, two- and three-level models in order to check for random effects on the party and country level. Since the effects remained robust across all models, I opted for a single-level multinomial regression. The multilevel models are available upon request.

${ }^{7}$ Party-competition data was taken from electoral websites of each country in the corresponding legislature and Adam Carr's Election Archive at http://psephos.adam-carr.net/. District magnitude was also taken from electoral or legislative institutions in each country. To measure incumbent status, I use the following survey question: "Is this your first time being elected to the legislature?" A " 0 " is assigned to newcomers and " 1 " is assigned to incumbents. For elected, appointed, and party office, survey questions were used in which legislators were asked what type of previous positions they have occupied and a " 1 " was assigned to those having occupied each position. The indicator for prospective loyalty is a continuous variable ranging from 1 to 4 that I logged for the analysis. The survey question asks: "To what extent do you value acquiring resources for your constituency during your legislative work?" Retrospective loyalty variables show the responsible factors in their electoral success and are also dummy variables. The question asks: "Who do you owe your election to?" A dummy variable is created for those who answered that they owe their election to the party leader, the party ideology, or the party program. 


\section{REFERENCES}

Altman, David. 2000. "The Politics of Coalition Formation and Survival in Multiparty Presidential Democracies." Party Politics 6(3):259-283.

Bell, Charles and Charles Price. 1969. "Pre-legislative sources of representational roles." Midwest Journal of Political Science 13(2):254-270.

Black, Gordon. 1972. "A Theory of Ambition: Career Choices and Role of Structural Incentives." American Political Science Review 66(1):144-159.

Borchert, Jens. 2011. "Individual ambition and institutional opportunity: A conceptual approach to political careers in multi-level settings." Regional and Federal Studies 21(2):117-40.

Botero, Felipe. 2008. Ambitious Career-Seekers: An Analysis of Career Decisions and Duration in Latin America. PhD thesis University of Arizona.

Botero, Felipe and Lucio Renno. 2007. "Career choice and legislative re-election: Evidence from Brazil and Colombia." Brazilian Political Science Review 1(1):102-124.

Cain, Bruce, John Ferejohn and Morris Fiorina. 1987. The Personal Vote: Constituency Service and Electoral Independence. Cambridge: Harvard University Press.

Camerlo, Marcelo. 2013. "Single-Party Cabinet and Presidential Democracies: the Argentine Case [in Spanish]." America Latina Hoy 64(1):119-42.

Camerlo, Marcelo. 2014. The Ministers of the President. Portfolio Allocation in Argentina. In The Selection of Ministers around the World, ed. Keth Dowding and Patrick Dumont. London: Routledge pp. 223-243.

Carey, John M. 1998. Term limits and legislative representation. Cambridge: Cambridge University Press.

Carey, John M. 2007. "Competing Principals, Political Institutions, and Party Unity in Legislative Voting." American Journal of Political Science 51(1):92-107.

Carey, John M. 2009. Legislative Voting and Accountability. New York: Cambridge University Press.

Carsey, Thomas M., Richard G. Niemi, Lynda W. Powell and James M. Snyder. 2008. "State Legislative Elections, 1967-2003." Study 21480. Inter-university Consortium for Political and Social Research.

Chasquetti, Daniel. 2010. Legislative Careers in Uruguay: A Study of Rules, Parties, and Legislators in the Chamber [in Spanish]. $\mathrm{PhD}$ thesis Universidad de la Republica.

Chasquetti, Daniel and Juan Pablo Micozzi. 2014. "The subnational connection in unitary regimes: Progressive ambition and legislative behavior in Uruguay." Legislative Studies Quarterly 39(2):87-112.

Colomer, Josep. 2011. Personal representation. The neglected dimension of electoral systems. Colchester: The ECPR Press.

Crisp, Brian and Felipe Botero. 2004. "Multicountry studies of Latin American legislatures: A review article." Legislative Studies Quarterly 29(3):329-356.

Desposato, Scott. 2006. "Parties for Rent? Ambition, Ideology, and Party Switching in Brazil's Chamber of Deputies." American Journal of Political Science 50(1):63-80.

Fox, Richard L. and Jennifer L. Lawless. 2005. "To run or not to run for office: Explaining nascent political ambition." American Journal of Political Science 49(3):642-59. 
Herrick, Rebekah and Sue Thomas. 2005. "Do Term Limits Make a Difference? Ambition and Motivations among US State Legislators." American Politics Research 33(5):726-47.

Jacobsen, Gary. 1989. "Strategic Politicians and the Dynamics of House Elections, 1946-86." American Political Science Review 83(3):774-791.

Jones, Mark P. 2002. Explaining the high level of party discipline in the Argentinan Congress. Cambridge: Cambridge University Press.

Karvonen, Lauri. 2010. The personalisation of politics. Colchester: ECPR Press.

Langston, Joy. 2011. "Governors and 'their' deputies: New legislative principals in Mexico." Legislative Studies Quarterly 35(2):235-258.

Leoni, Eduardo, Carlos Pereira and Lucio Rennó. 2004. "Political Survival Strategies: Political Career Decisions in the Brazilian Chamber of Deputies." Journal of Latin American Studies 36(1):109-130.

Lodola, Germán. 2009. "The subnational structure of political careers in Argentina and Brazil [in Spanish]." Desarrollo Economico 49(194):247-286.

Luna, Juan Pablo. 2007. "Representation in Latin America: State of Research and Research Proposal [in Spanish]." Politica y Gobierno 14(2):391-435.

Maestas, Cheri. 2000. "Professional Legislatures and Ambitious Politicians: Policy Responsiveness of State Institutions." Legislative STudies Quarterly 25(4):663-690.

Maestas, Cheri, Sarah Fulton, Sandy Maisel and Walter Stone. 2006. "When to Risk It? Institutions, Ambition, and the Decision to Run for the US House." American Political Science Review 100(2):195-208.

Maestas, Cherie. 2003. "The Incentive to Listen: Progressive Ambition, Resources, and Opinion Monitoring among State Legislators." The Journal of Politics 65(2):439-456.

Martínez Rosón, Maria del Mar. 2011. “Ambición política y lealtad: Influencia sobre el comportamiento político.” Política y Gobierno 18(2):231-264.

Mayhew, David. 1974. Congress: The Electoral Connection. New Haven: Yale University Press.

Meserve, Stephen A., Daniel Pemstein and William T. Bernhard. 2009. "Political ambition and legislative behavior in the European Parliament." The Journal of Politics 71(3):1015-1032.

Micozzi, Juan Pablo. 2013. "Alliance for progress? Multilevel ambition and patterns of cosponsorship in the Argentine House." Comparative Political Studies 47(8):1186-1208.

Micozzi, Juan Pablo. 2014. "From house to home: Strategic bill drafting in multilevel systems with non-static ambition." Journal of Legislative Studies 20(3):265-284.

Morgenstern, Scott and Benito Nacif. 2002. Legislative politics in Latin America. Cambridge: Cambridge University Press.

Müller, Wolfgang C. 2000. "Political Parties in Parliamentary Democracies. Making Delegation and Accountability Work." European Journal of Political Research 37(3):309-333.

Müller, Wolfgang C. and Kare Strom. 1999. Policy, office, or votes? How political parties in Western Europe make hard decisions. Cambridge: Cambridge University Press.

Rohde, David. 1979. "Risk Bearing and Progressive Ambition." American Journal of Political Science 23(1):1-26.

Samuels, David. 2003. Ambition, federalism, and legislative politics in Brazil. Cambridge: Cambridge University Press. 
Samuels, David. 2011. "Political ambition, candidate recruitment, and legislative politics in Brazil [in Spanish] ." POSTData 16(2):281-309.

Schlesinger, Joseph A. 1966. Ambition and politics: Political careers in the United States. Chicago: Rand McNally.

Siavelis, Peter M. and Scott Morgenstern. 2008a. "Candidate recruitment and selection in Latin America: A framework for analysis." Latin American Politics and Society 50(4):27-58.

URL: http://www.jstor.org/stable/30130894

Siavelis, Peter and Scott Morgenstern. 2008b. Pathways to power: Political recruitment and candidate selection in Latin America. University Park: Penn State Press.

Strøm, Kare. 1997. "Roles, reasons, and routines: Legislative roles in parliamentary democracies." Journal of Legislative Studies 3(1):155-174.

Taylor, Michelle. 1992. "Formal versus informal incentive structures and legislator behavior: Evidence from Costa Rica." The Journal of Politics 54(4):1053-1071.

Thomsen, Danielle. 2014. "Ideological moderates won't run: How party fit matters for partisan polarization in Congress." Journal of Politics 76(3):786-797.

Treul, Sarah. 2009. "Ambition and party loyalty in the U.S. Senate." American Politics Research 37(3):449-464.

Victor, Jennifer Nicoll. 2011. "Legislating versus Campaigning: The Legislative Behavior of Higher-Office Seekers." American Politics Research 39(1):3-31. 